\title{
Sermons in stones, or how many kick-ups can you do?
}

For my thirteen-year-old son, the question is an important one. Obsessed with football as a player, a spectator, a habitue of the virtual footballing worlds of PlayStation games and of website fanzines and discussion boards, he spends hours attempting to keep a football in the air. Each contact with the ball - each kick-up - scores one. He is engaged in an unending struggle with gravity, seeking to improve on his own personal best - 87, I think, at the last count. He knows the personal bests of all his friends. Numbers matter in this. There are targets to be reached, strict arithmetic comparisons to be made. But there is also a question of style. Alongside the quest for a higher total, there is a constant striving for novelty, for grace, for a fitting climax. In one variation, the ball ends up nestling between the shoulder blades. Kick-ups are a performance, a demonstration of skill that is meant to impress one's audience. My son is not alone. Kick-ups are an elaborate code, manifested in playgrounds and parks across the country (as well as in footwear and sportswear adverts). Even the football can be dispensed with. I have seen the deftest, most extravagant displays of kick-ups performed with tennis balls, balls of screwed-up file paper and even, on one occasion in a classroom I had just entered for a cover lesson, a perfectly-executed kick-up routine which culminated in a pencil-sharpener being rolled along the shoulders before being volleyed across the room into the wastepaper bin.

The ability to do kick-ups is a highly-prized skill. It is closely associated with a consuming interest in football. It demonstrates an ability to control the ball, to bring ball and body into harmony. And yet no-one would dream of judging anyone's ability as a football player on the basis of their ability to do kick-ups. To suggest that the two could be conflated, that one could stand as a proxy indicator for the other, would be to invite ridicule.

Doing kick-ups is a solitary pursuit: the one with the ball (or even the pencil-sharpener) exists in a curious kind of bubble, the performance space created by the performance. Playing football, on the other hand, is a collaborative activity. It is not enough to control the ball. One must be constantly aware of others, opponents and team-mates. The game is wholly inextricable from the complex, forever shifting, nexus of relationships, of tactics and strategies that are contingent, context-related. A footballer without a sense of these contexts would be no player at all. (And any football manager who bought, sold or selected players on the basis of the number of kick-ups they could do would not last five minutes.)

So what's my point? Merely this. That in vast areas of public discourse about literacy and in much of the practice that goes on within education, we behave as if the linguistic equivalents of kick-ups were all that mattered.

We break complex activities like reading and writing down into single, isolable skills (spelling, for example). We focus on these skills at word or sentence level. We teach our students these skills. We expect our students to perform endless drills, practising these skills in carefully controlled conditions. We test our students on the skills in which they have been coached. And then, on the basis of these test results, we make large statements about their competence as readers and writers.

You wouldn't assume that someone was a good footballer because s/he could volley a pencil sharpener into a bin. Yet the overarching assumption is that it is both possible and desirable to break down complex activities in this way. We can help children to be betters readers and writers by focusing on spellings. We can check that they have, indeed, become better readers and writers by testing whether they spell accurately. There are clear advantages to this 
approach. It is much easier - much more manageable - to focus on one aspect of a complex activity than to attempt to encompass the whole. And it is certainly much easier to test competence in a single skill than in the complex activity. Whether you're being asked to spell meat or metempsychosis, your arrangement of letters will be either right or wrong. A spelling test can thus produce a score that is as neat, as irrefutably factual, as the number of kick-ups you can do.

Up until 2003, the Key Stage 1 SATs spelling test was marked in such a way that children who used the correct initial letter for a word were given some credit for doing so, while those who spelled the whole word correctly were given more marks. From 2003 onwards, children will only gain marks for spelling the whole word correctly. At first sight, this change in assessment procedures might seem to have much to recommend it. It might, indeed, be seen as a more rigorous approach. Spellings are, after all, either right or wrong.

What is interesting about this change is that it enacts a recognisable process, a fossilisation of the mark scheme, as it were. First, the specific skill (in this case, the ability to spell words correctly) is isolated. Then it is taught and tested for. Later, the testing regime is refined, simplified, endued with greater rigour and transparency. But this subsequent tweaking of the rules takes the assessment process further away from the complex activity from which the skill had been abstracted. When children were given some credit for choosing the correct initial letter, the mark scheme still bore traces of an awareness that an assessment of spelling might shed some light on a child's understanding of grapho-phonic correspondence - that certain letters tend to represent certain sounds - and that this might be taken as evidence of a child's knowledge of how writing (some forms of writing) works. Once credit was only given for the correct spelling of a whole word, then the mark scheme only rewarded utterly specific right answers. In this assessment regime, the ability to spell chocolate tells the assessor nothing at all about the child's ability to spell any other word whatsoever - whether chipmunk or china or chiaroscuro. The assessment data no longer can even pretend to gesture at a larger truth, a bigger picture.

In the past two decades, much of the debate on assessment has tended to focus on the question of the reliability of modes of assessment. We privilege hard, quantitative data over soft, qualitative data, public, externally set and marked terminal examinations over coursework and continuous assessment. What has often been neglected in this debate has been the issue of what exactly is being assessed, and why.

Even when it is conducted with a far greater degree of sophistication and complexity, the kick-up model of assessment still seems to me to pose big problems.

The continuous writing that students produce in their GCSE English exams is, to a large extent, assessed impressionistically and holistically, against broad grade criteria. Some years ago, the Qualifications and Curriculum Authority commissioned research on a sample of GCSE English scripts (QCA, 1999). Scripts that had been awarded different grades were analysed for their use of subordinate clauses, sentence lengths and a whole battery of other features of written language. In one sense, what the research revealed was that there were ("objective"), quantifiable features in the students' writing which correlated closely with the grades awarded through a marking process that does not encourage the marker to isolate and then grade separable aspects of pieces of writing. But the claims made on behalf of this research project went much further. Given that the research had identified surface features of the scripts that seemed to have a significant bearing on the grade awarded, it must have seemed natural to have moved from description to prescription, from assessment to 
pedagogy: if this is what an A grade essay looks like, the argument goes, if these are the linguistic characteristics of an A grade answer, then surely it is reasonable for teachers to teach these linguistic features to their GCSE students? If students need to use subordinate clauses to get a certain grade, then shouldn't their teachers teach them about subordinate clauses?

Now don't get me wrong. I am in favour of writers adopting conventional spelling - it makes the reader's task easier. And I am a fan of subordinate clauses and of all students extending their control over as broad a range of syntactical forms as possible. But I remain bothered by what seems to me to be a Gradgrindian approach to writing. Do students become more adept at using subordinate clauses because they have been taught to use them, or because they have developed their cognitive and linguistic powers to the point where what they are thinking and what they wish to express in writing can best be expressed using (some) subordinate clauses?

The former approach seems to me to take us back to the realm of the kick-ups.

As any 13-year-old will tell you, there is no simple correlation between mastery of the art of kick-ups and being any good at football. Nevertheless, you can be pretty damn sure that those poor unfortunates who have no interest in football will not have developed the ability to do kick-ups. What comes first, in other words, is the passion for football. The motivation to hone one's skill at kick-ups is a by-product of this passion, not a precondition of it. And what I want to suggest is that affective factors are just as important in the development of writing repertoires and the effective use of subordinate clauses.

This argument could be misconstrued as one which, in effect, limits the demands that we might make on students to the immediate, the local. This is not what I mean, though my experience over twenty years in school has been that many students do write beyond themselves - beyond the formal, grammatical and lexical limits of their hitherto-revealed competence - when they are fully engaged in the content of their writing. Here, to take only one example, is Amani, a young Palestinian woman, only recently arrived in London, writing in English with a fluency and power that was, to me as her teacher, totally unexpected:

Sound like millions of Palestinian people saying the same words. It's not fair that our children die and they don't do nothing. It's just because they want their land.

All this time keeping the wounds in their heart. The wish that their boat of wounds would stop. And to live in peace all the time, But all our life is darkness. The earth's trees have become tears on heaven's cheeks ...'

The significance of Amani's efforts is, I think, very simple: students are more likely to write, and to write well, when they have something to say. I am reminded here of the first sonnet in Philip Sidney's Astrophil and Stella sequence (Sidney, 1973):

Loving in truth, and fain in verse my love to show, 
That she (dear she) might take some pleasure of my pain;

Pleasure might cause her read, reading might make her know,

Knowledge might pity win, and pity grace obtain;

I sought fit words to paint the blackest face of woe,

Studying inventions fine, her wits to entertain;

Oft turning others' leaves to see if thence would flow

Some fresh and fruitful showers upon my sun-burnt brain.

But words came halting forth, wanting invention's stay;

Invention, nature's child, fled step-dame study's blows,

And others' feet still seemed but strangers in my way.

Thus, great with child to speak, and helpless in my throes,

Biting my truant pen, beating myself for spite,

'Fool,' said my muse to me; 'look in thy heart and write.'

I am not for a moment insisting on a naïve reading of this highly-wrought text. What is going on in Sidney's sonnet is, of course, a dazzling display of linguistic and poetic virtuosity metrically innovative in its use of alexandrines and intensely, punningly playful in its lexical choices. And I am aware of the extent to which the poem's resolution depends on an appeal to sincerity that is itself conventional in the genre of love poetry within which Sidney was writing. The explosive, dramatic outburst of the last line does, nonetheless, deserve to be inscribed above every whiteboard in every classroom in the land.

I want now to turn to what happens to students as readers ("studying inventions fine ... oft turning others' leaves"). The argument about the texts that students read, or should read, is frequently couched in terms of a set of simple binary oppositions: great literature/pulp fiction; canonical/non-canonical texts; worthy of serious study/unworthy of serious study; the Great Tradition/multicultural literature. In the blue corner are ranged those who maintain a belief in the intrinsic, timeless value of certain texts. In the red corner, those who argue that texts should have some relevance to particular sets of readers, or even that the texts should be in some sense representative of readers and groups of readers. And often, of course, the argument has been couched less in terms of the choice of texts to be read than as a set of wild accusations about censorship.

To advance the case that a particular text - Underground to Canada, let's say, or To Kill A Mockingbird - should not be on a prescribed reading list is not, I should make clear, the same thing at all as wanting to see a book banned. ${ }^{2}$ To contest the place that is afforded to Shakespeare within the field of English studies is not to engage in book burning. (And, it should scarcely be necessary to point out, all choices are also exclusions.)

What interests me more than these abstract polarities is how complicated readers' interactions with texts actually are. It does seem to me to be useful to consider how a particular group of readers is going to find a way into a text, to recognise that the concept of difficulty is not just about the words or ideas in a text but to do with the accessibility of a text to particular readers. My point, though, is that it would be a mistake to take a schematic view of this relationship, to assume that distance in time or place is in itself necessarily a barrier to understanding, engagement or enjoyment.

Last year I read Larkin's The Whitsun Weddings (Larkin, 1964) with a group of AS students. I did not anticipate that the poems, most of which had been written in my lifetime, would present huge difficulties for the students. Larkin's aesthetic, after all, was one that had been 
defined in opposition to the polyglot difficulty, the insistent intertextual allusiveness of modernism. In language, in content, in form, shouldn't these poems have been, well, accessible? And yet the world in which they were written, the world that they evoke and that is often their subject-matter, appeared an impossibly distant one. What sense could my multilingual, multiethnic, cosmopolitan North London students make of postwar, provincial Hull?

Now literature, you might say, is meant to be about other worlds, other ways of seeing. And that's a fair point. But I couldn't help feeling that my students were right to question the value of dwelling on a point of view as narrowly circumscribed, as jaundiced and as outmoded as Larkin's. They could see that Larkin was capable, in poems such as "Dockery and Son" and "Mr Bleaney", of being as rigorously unsentimental an observer of himself as of anyone else. They could appreciate the strange optimism of "First Sight" or "For Sidney Bechet". But still, overall, here was a poet who inhabited and described a world and a set of values that could not have been more remote from anything that my sixth-formers had experienced or could envisage. In part, of course, this has to do with the fact that the Larkin of Whitsun Weddings is not just the wrong side of forty but a middle-aged man with his eyes already firmly fixed "down Cemetery Road" ("Toads Revisited"). More significant than this, though, is that the assumptions that Larkin makes, the readers for whom he writes, are both monocultural and male.

In reading the poems with my students, it was impossible not to register the profound transformation in British society over the past forty years. The distance we have travelled was suggested in details. When we read "Here", the students came across the mention of "grim head-scarfed wives": they assumed that Larkin was seeing women wearing the hijab.

What, then, would these same students make of Marlowe's Dr Faustus? How much more remote, I wondered, would a late-sixteenth-century play be? We assume that the difficulties are there on the page - at word or sentence level - when context is, if not everything, then certainly much more than we bargain for. We assume that less is more accessible, that modern is more accessible, when it ain't necessarily so. In the case of Dr Faustus, for example, what made the Manichean morality-play convention of the Good and Evil Angel instantly recognisable - and unproblematic - for my students was that almost all of them had already encountered the same means of rendering a moral dilemma in the cartoon iconography of The Simpsons.

Both The Whitsun Weddings and Dr Faustus appear as part of the same AS unit (AQA English Literature syllabus), under the heading "Texts in context". When we read $D r$ Faustus, I wanted students to think about some of the contexts in which the play had been produced. To start them off, and to help them to realise how much they already knew, I began one lesson with a question. Why, I asked, was Faustus a man? I explained that I didn't want answers to the question so much as a list of the different bits of contextual knowledge that might enable them to provide answers to this question.

In groups, students came up with some fairly impressive ideas. They referred to the conditions of theatrical production - to the fact that all the parts in an Elizabethan theatre were taken by men and boys. (In 1594, moreover, when the play was first performed, it was still less than twenty years since the establishment of the first permanent theatre in London. Another decade was to pass before the standard of acting by the boys - some boys, or perhaps just one extraordinarily talented star - was sufficiently high for Shakespeare to dare to write 
parts such as Cleopatra - and lines as archly self-referential as that where Cleopatra anticipates a time when she will see "Some squeaking Cleopatra boy [her] greatness/I'th' posture of a whore" [Shakespeare, 1995].) My students looked at the relationship between Marlowe and Faustus - at the last lines of the play, that slide from Faustus to his creator, eliding the two:

Cut is the branch that might have grown full straight,

And burned is Apollo's laurel bough, That sometimes grew within this learned man (Marlowe, 1989).

They also considered the position of Faustus at the start of the play, alone in his study in the university of Wittenburg. They remembered, with some prompting, what they had learned elsewhere about the gendered exclusivity of schools and universities in sixteenth-century Europe - the fact that Faustus, though born of "parents base of stock", as it says in the opening Chorus, could gain admission - but any sister of Faustus would have had no such opportunity.

And something interesting happened with at least one of the groups who were discussing my simple question. Shahanara and her friends, five young women of Bangladeshi origin, became increasingly animated. Their discussion was about the unfairness of an education system from which women were excluded - so that, in some rather obvious and hopelessly ahistorical way, they could be seen to be assuming the role of Faustus' hypothetical sisters. But maybe it wasn't quite as simple as this would suggest. For they, like Faustus, were conducting this discussion from within the academy, a place where they had chosen to be, a place to which their own prior academic achievements had given them access. They were also, like Faustus, in uncharted territory, negotiating their way through curricula of which their parents would have had no experience - and curricula which might well be deemed to stand in an uncertain, somewhat heterodox, relationship to the rules and expectations of their families' culture and religion. From such a perspective, the feminist critique of sixteenthcentury theatrical or educational institutions could be seen as providing an opportunity for Shahanara and her friends to reflect on their own positioning, not just in relation to the text that we were reading together but to the context in which that text was being read - the context of the classroom and the context of the post-compulsory, A-level course.

What makes me confident of such a hypothesis? Simply the vehemence of the discussion the fact that all the students were engaged in it, and engaged in it in a way that demonstrated that it mattered to them - and all this from a group of students who had treated Larkin and my attempts to enliven The Whitsun Weddings with, at best, polite indifference. In a sense, I regret the fact that I do not have more objective or quantifiable evidence. I wish that I had taped the discussion, so that I could quote accurately from it. But I wonder if this might not be part of the moral of this story. The literacy version of kick-ups bothers me partly because it encourages teachers to pay attention only to those facets of language and literacy development that are quantifiable. The progress that matters most, however, can sometimes only be discerned in the quality of - inevitably ephemeral - classroom interactions. If my students were still "turning others' leaves", they had somehow managed in this moment to make those leaves their own, to look, if not in their own hearts, then certainly at the ways in which their own subjectivities were being shaped, and read. 
Larkin, P. (1964) The Whitsun Weddings, London: Faber \& Faber

Marlowe, C. (1989) Dr Faustus, ed. Roma Gill, London: A\&C Black (New Mermaids series)

QCA (1999) Technical accuracy in writing in GCSE English: research findings London: QCA

Saney, I. (2003) “The case against To Kill a Mockingbird”, Race \& Class, 45.1, pp. 99-105

Shakespeare, W. (1995) Antony and Cleopatra, ed. John Wilders, London \& New York:

Routledge

Sidney, P. (1973) Sir Philip Sidney: Selected Poems, ed. Katherine Duncan-Jones, Oxford 
1 From "Wound", by Amani Khreibi. The poem was Amani's entry in a competition organised at my previous school. The competition used Martin Luther King's "True peace is not the absence of conflict but the presence of justice" as a stimulus for students' writing.

2 For an illuminating account of a recent controversy, see Saney (2003). 